Vol. 44, N. 2 : pp. 113 - 119, June, 2001

ISSN 1516-8913 Printed in Brazil

\title{
Microflora Dynamics in Earthworms Casts in an Artificial Soil (Biosynthesol) Containing Lactic Acid Oligomers
}

\author{
Nathalie Alauzet ${ }^{1}$, Sevastianos Roussos ${ }^{2}$, Henri Garreau ${ }^{1 *}$ and Michel Vert ${ }^{1}$ \\ ${ }^{1}$ CRBA CNRS-UPRESA 1465, Faculté de Pharmacie, 15 av. C. Flahault, 34060 Montpellier, France \\ ${ }^{2}$ Equipe de Mycologie-FMS, URI19-IRD, IFR-BAIM, Universités de Provence et de la Méditerranée, ESIL Case \\ 925, 163, av. de Luminy, 13288 Marseille cedex 9, France
}

\begin{abstract}
Studies were performed to appreciate the presence of micro-organisms able to degrade OLA, in earthworms casts or in the surroundings. Worms were grown in biosynthesol, an artificial soil. The counting of bacteria and fungi in earthworms casts and in biosynthesol without earthworms suggested that earthworms ate some of the microorganisms. The main filamentous fungi genera found were Aspergillus, Trichoderma, Fusarium and Penicillium. Previous results in the literature have shown that some species from the Aspergillus and Fusarium genera were able to degrade OLA and other aliphatic esters. It could be suggested that these two genera and some bacteria were responsible for the pre-degradation of OLA, and that earthworms might eat them.
\end{abstract}

Key words: Earthworm, Eisenia andrei, biodegradation, lactic acid polymers, artificial soil, natural microflora

\section{INTRODUCTION}

Biodegradable plastics are considered as one of the solutions to reduce the nuisance of plastic wastes to the environment. Among degradable polymers, polylactic acids (PLA) are promising for industrial applications, and various companies such as DowCargill are planning to produce and use as packagings stereocopolymers of the PLAX-type (acronym where $\mathrm{X}$ stands for the percentage in Llactyl units, according to Vert et al., 1981). The abiotic hydrolysis of PLA is well documented ( $\mathrm{Li}$ et al., 1990a, Vert et al., 1994). In aqueous media, many factors can contribute to modulate the degradation characteristics of PLAX polymers ( $\mathrm{Li}$ et al., 1990b). Ester hydrolysis is dependent on autocatalysis by carboxylic chain ends and from diffusion-reaction phenomena involving absorbed water and oligomeric molecules generated by degradation via their solubility in aqueous environment. When submitted to water and heat, high molecular weight (HMW) PLA degrades to low molecular weight PLA (oligomers) up to dimers and monomers of lactic acid. This explains why PLA can degrade in a humid and warm medium like a compost (Buchanan et al., 1995, Alauzet, 1999) or a vermicompost (Alauzet, 1999). HMW PLA has never been shown to be biodegraded by living organisms, although PLA 50 plates left 8 weeks in a soil were invaded up to the bulk by filamentous fungi after further incubation for 8 weeks under culture conditions (Torres et al., 1996a). However some of the byproducts can be assimilated by micro-organisms (Torres et al., 1996b, Karjomaa et al., 1998). Torres et al. (1996c) found a bacterium

Author for correspondence 
(Pseudomonas putida) and a fungus (Fusarium moniliforme) that were able to bioassimilate lactic acid oligomers (OLA) according to acronyms proposed by Vert and Guérin (1992). Furthermore, some strains of the fungus Aspergillus niger have been identified as able to degrade other aliphatic polyesters (Nishida and Tokiwa, 1993, Gonsalves et al., 1992). Recent investigations (Alauzet, 1999) have shown that earthworms placed into biosynthesol (Bouché et al., 1998), an artificial soil modified from Abdul Rida and Bouché (1997) and containing only OLA as carbon source, are able to bioassimilate OLA after a previous digestion by micro-organisms. The microorganisms found in the gut of earthworms seem to be the same as in the surrounding environment (Morgan, 1988), but their number fluctuate after passing through the earthworm gut (Parle, 1963). In this work, we wish to report the results of an investigation aimed at showing the presence of micro-organisms able to degrade OLA in earthworms casts; For this, a comparison quantitative of microflora present in earthworms casts and in biosynthesol without earthworm was made. Identification of filamentous fungi present in biosynthesol and in earthworms casts was also undertaken.

\section{MATERIAL AND METHODS}

Chemicals. OLA $50 \quad(\overline{\mathrm{M}} \mathrm{p}=825, \quad \overline{\mathrm{M}} \mathrm{n}=500$, $\mathrm{I}=1,68)$, and OLA $96 \quad(\overline{\mathrm{M}} \mathrm{p}=730, \quad \overline{\mathrm{M}} \mathrm{n}=460$, $\mathrm{I}=1,55)$ were synthesized by heating D,L-lactic acid and L-lactic acid (Sigma) in aqueous solution at $120^{\circ} \mathrm{C}$ for $18 \mathrm{~h}$ under progressively reduced pressure up to $17 \mathrm{mmHg}$ (Alauzet, 1999).

\section{Culture media:}

(1) Biosynthesol. The medium in which the earthworms grew was modified from the biosynthesol used by Abdul Rida and Bouché (1997) according to Alauzet (1999)@. The medium was composed of pure Levilite $\AA$ (Prolabo) $45 \mathrm{~g}, 45$ glass balls of 1.5 to $2 \mathrm{~cm}$ in diameter (Vetrotex, ref. E14,5g), glucose $0.9 \mathrm{~g}$, $\mathrm{NH}_{4} \mathrm{NO}_{3} \quad 0.1$ g (nitrogen source), modified Winogradsky solution $112 \mathrm{ml}$, OLA 50 or OLA 96 $2 \mathrm{~g}$ (carbon source). The modified Winogradsky solution was composed of $\mathrm{MgSO}_{4}, 7 \mathrm{H}_{2} \mathrm{O} 600$ $\mathrm{mg} / \mathrm{l}, \mathrm{MnSO}_{4} 20 \mathrm{mg} / \mathrm{l}, \mathrm{Fe}_{2}\left(\mathrm{SO}_{4}\right)$ 80, $\left(\mathrm{NH}_{4}\right)_{2} \mathrm{SO}_{4}$
$200 \mathrm{mg} / \mathrm{l}, \mathrm{ZnSO}_{4}, 7 \mathrm{H}_{2} \mathrm{O} 20 \mathrm{mg} / \mathrm{l}, \mathrm{CuSO}_{4} 20 \mathrm{mg} / \mathrm{l}$, $\mathrm{Na}_{2} \mathrm{HPO}_{4} 4 \mathrm{~g} / \mathrm{l}, \mathrm{KH}_{2} \mathrm{PO}_{4} 2.1 \mathrm{~g} / \mathrm{l}, \mathrm{CaCO}_{3} 2 \mathrm{~g} / \mathrm{l}$. Biosynthesol was dispatched in one liter jars (Figure 1), agitated, then let non-sterile at $25^{\circ} \mathrm{C} .10$ earthworms per jar were added after 13 days of incubation when the $\mathrm{pH}$ of the medium was stabilized at 6.8/7.2.

(2) Plate Count Agar or PCA (Difco) with $0.1 \mathrm{~g} / \mathrm{l}$ of cycloheximide in Petri dishes was used for bacterial counting. For anaerobic bacteria, the Petri dishes were incubated in anaerobic jars, with Microcult A plaques (Merck). Cultures were incubated at $25^{\circ} \mathrm{C}$ for 2 and 7 days.

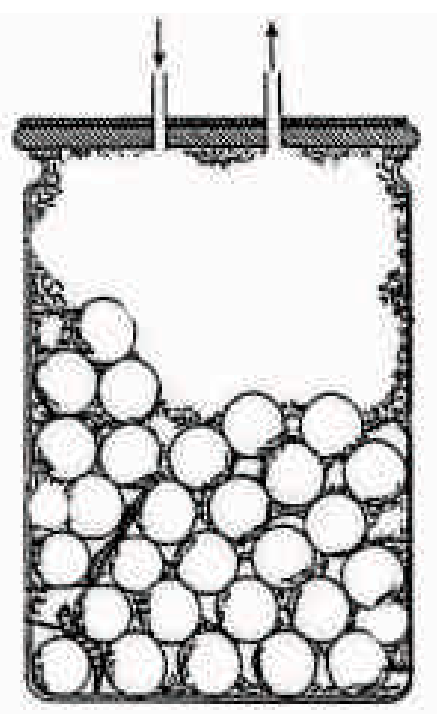

Figure 1 - Experimental device used for bioassimilation determination (biosynthesol).

(3) Potato Dextrose Agar or PDA (Difco), alone was used in Petri dishes for genus identification, and with $0.05 \mathrm{~g} / \mathrm{l}$ of Rose Bengal (Sigma) and 0.1 $\mathrm{g} / \mathrm{l}$ of chloramphénicol for fungal counts.

Earthworms: An epigeic species, Eisenia andrei Bouché 1972, was used. Adult worms, i.e. weighing more than $300 \mathrm{mg}$ each, were collected from the Soil Zooecology Laboratory in Montpellier.

\section{Sampling: Earthworms epidermal microflora:} 10 adult worms taken from their culture medium were washed twice with sterile physiological water $(\mathrm{NaCl} 0,9 \%)$ containing $0.01 \%$ of Tween 80 , rinsed and finally introduced in $50 \mathrm{ml}$ of sterile physiological water. The container was slightly 
agitated for $3 \mathrm{~min}$ and the worms were removed from the water. Dilutions (1/10) were made from this suspension.

Earthworms casts: Earthworms casts were regularly sampled in biosynthesol. Glass balls were first taken out, then the 10 earthworms were washed 3 times with sterile water and let $18 \mathrm{~h}$ in humidified Petri dishes. The casts present in Petri dishes were then introduced in $50 \mathrm{ml}$ of physiological water, and homogenised using an ultraturrax. Dilutions (1/10) were made from this suspension. The weight of fresh casts was determined by weighing earthworms before and after defecation (after $18 \mathrm{~h}$ ). Earthworms were then re-introduced into biosynthesol.

Biosynthesol: About $2 \mathrm{~g}$ of biosynthesol were sampled, scraping from the bottom of the jar for optimal sampling. The $2 \mathrm{~g}$ were then split in 2 parts. About $1 \mathrm{~g}$ was weighed, dried at $105^{\circ} \mathrm{C}$ for $24 \mathrm{~h}$ to determine the dry weight, and the rest was also weighed, then mixed with $50 \mathrm{ml}$ of physiological water and homogeinised with ultraturrax mixer. Dilutions (1/10) were made and microflora dynamics were evaluated.

Analysis: Numeration: For each dilution, $200 \mu \mathrm{l}$ were sampled and inoculated on Petri dishes containing PCA for bacterial counts (aerobic or anaerobic) and PDA for fungal counts. All Petri dishes were then incubated at $25^{\circ} \mathrm{C}$. Microflora counting was done after 2 and 7 days of incubation.

Determination of fungi. From each Petri dish, the main genus were isolated on a PDA medium without Rose Bengal. After 3-5 days, mycelia were sampled and observed with an optic microscope. Fungi genus were then determined through morphological criteria using identification keys such as the description of mycelia and of asexual reproduction forms (Domsch et al., 1980).

\section{RESULTS AND DISCUSSION}

Natural microflora of earthworm epidermis: Before counting the microflora of earthworms casts, it was necessary to count the epidermal microflora, as the latter could contaminate the casts. The counting of epidermal microflora is shown in Table 1. Aerobic bacteria were predominant compared to the fungal population.
The results of epidermal microflora counting are taken into consideration in the calculation of earthworms casts microflora counting.

Table 1 - Counting of earthworms epidermal microflora (results are given in cultivable cells/single earthworm).

\begin{tabular}{lcc} 
Aerobic & \multicolumn{2}{c}{ Incubation time at $25^{\circ} \mathrm{C}$} \\
Microflora & 2 days & 6 days \\
\hline bacteria & $3.010^{5}$ & $1.410^{6}$ \\
Fungi & $6.010^{3}$ & $8.010^{3}$ \\
\hline
\end{tabular}

Aerobic bacteria and fungi present in biosynthesol containing OLA 50 and OLA 96 without earthworm: The counting of bacteria and fungi that grow in biosynthesol in the presence of OLA 50 or 96 for 2 and 7 days of incubation at $25^{\circ} \mathrm{C}$ are shown in the Figure 2 . The number of micro-organisms was more or less the same, whether after 2 or 7 days of Petri dishes incubation, indicating that those micro-organisms had a rapid growth. For bacteria, the growing phase was very short (less than 3 days). Their number then reached a stationary phase. For fungi, their growing phase lasted 7 days. Beyond, the population decreased regularly. Bacterial or fungal growth rates were comparable whether the sole carbon source was OLA 50 or OLA 96.

Aerobic bacteria and fungi present in earthworms casts in a biosynthesol containing OLA 50 or OLA 96: In a biosynthesol without earthworm, the number of bacteria and fungi was higher than in a real soil (Figure 3). A quantity of $10^{9}$ to $10^{10}$ bacteria/g of biosynthesol was found, instead of the expected $10^{8}-10^{9}$ in a real soil, and $10^{8}$ fungi/g of biosynthesol instead of the expected $10^{6}$ (Prescott et al., 1996). After transit through the earthworm gut, the number of bacteria and fungi also decreased and were close to the population found in normal soil. The number of fungi decreased down to $10^{6}$, and that of bacteria down to $10^{8}$. Therefore, earthworms seem to regulate the number of micro-organisms by consuming some of them, and also by stimulating the development of others thanks particularly to their intestinal mucus which can be used as nutrient (Cortez and Bouché, 1998). 

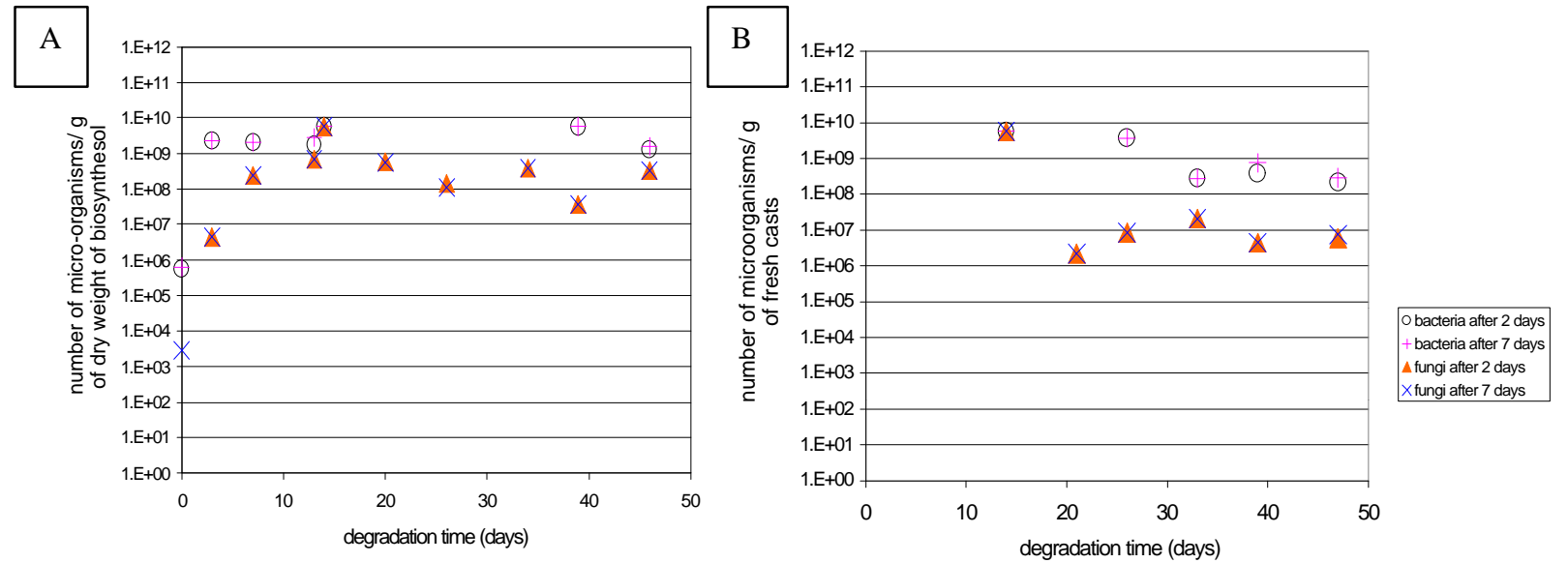

Figure 2 - Counting of micro-organisms versus time: A) in biosynthesol without earthworm, containing OLA 50 as sole carbon source B) in E. andrei casts, with OLA 50 as sole carbon source.
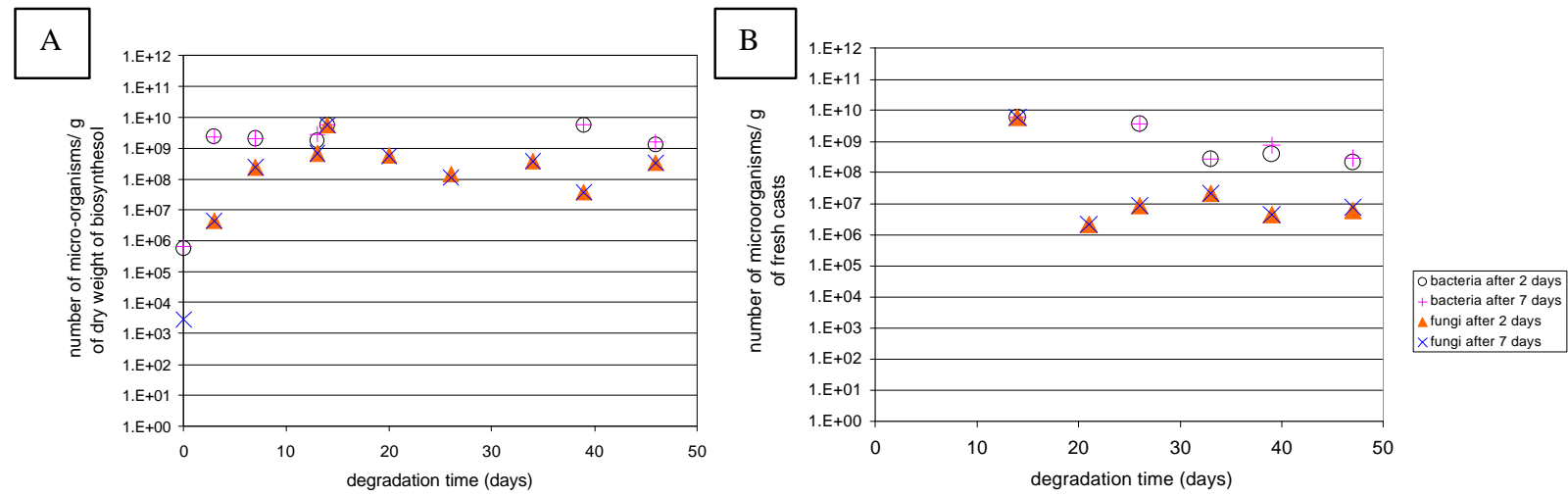

Figure 3 - Counting of micro-organisms versus time: A) in biosynthesol without earthworm, containing OLA 96 as sole carbon source; B) in E. andrei casts, with OLA 96 as sole carbon source.

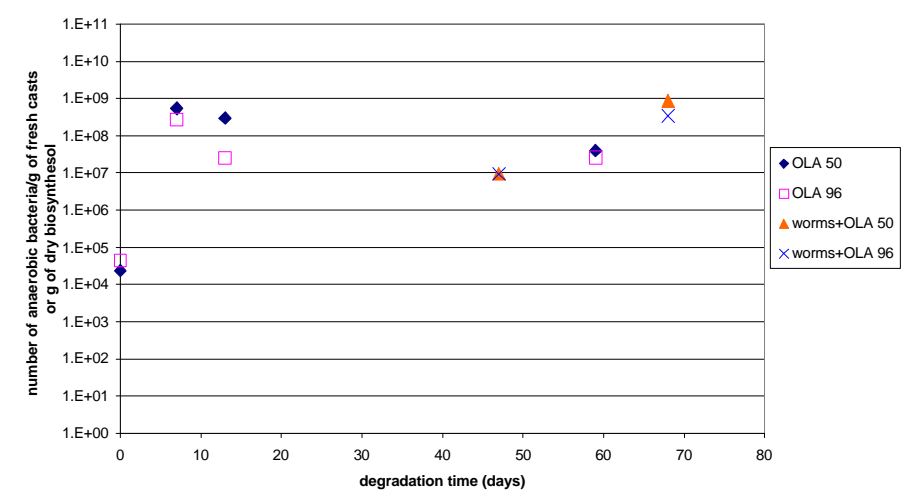

Figure 4 - Counting of anaerobic microflora in biosynthesol without earthworm and in E. andrei casts. 
Table 2 - Percentage of the main fungal genus found in the biosynthesol or in earthworms casts.
(a) in biosynthesol with OLA 50 as sole carbon source
(b) in biosynthesol with OLA 96 as sole carbon source
(c) in E.andrei casts with OLA 50 as sole carbon source
(d) in E.andrei casts with OLA 96 as sole carbon source

(a)

\begin{tabular}{|c|c|c|c|c|c|c|c|c|c|c|}
\hline degradation time (days) & 3 & 7 & 10 & 14 & 20 & 26 & 32 & 39 & 46 & 59 \\
\hline Aspergillus & 100 & 100 & 100 & 87 & 57 & & & 7 & 31 & 13 \\
\hline Trichoderma & & & & 13 & & & 12 & & & \\
\hline Penicillium & & & & & 43 & 62 & 52 & & 22 & 50 \\
\hline Fusarium & & & & & & 38 & 36 & 93 & 29 & 37 \\
\hline others & & & & & & & & & 18 & \\
\hline
\end{tabular}

(b)

\begin{tabular}{lllllllllll}
\hline degradation time (days) & $\mathbf{3}$ & $\mathbf{7}$ & $\mathbf{1 0}$ & $\mathbf{1 4}$ & $\mathbf{2 0}$ & $\mathbf{2 6}$ & $\mathbf{3 2}$ & $\mathbf{3 9}$ & $\mathbf{4 6}$ & $\mathbf{5 9}$ \\
\hline Aspergillus & 100 & 100 & 100 & 66 & 50 & & & 16 & 14 & 5 \\
Trichoderma & & & & 34 & & 28 & 16 & 26 & 9 & 10 \\
Penicillium & & & & & 50 & 39 & 28 & 10 & 41 & 48 \\
Fusarium & & & & & & 33 & 56 & 48 & 8 & 12 \\
others & & & & & & & & & 28 & 25 \\
\hline
\end{tabular}

(c)

\begin{tabular}{|c|c|c|c|c|c|c|c|c|c|c|}
\hline degradation time (days) & 7 & $\mathbf{1 0}$ & 14 & 21 & 26 & 33 & 39 & 46 & 59 & 68 \\
\hline Aspergillus & & & & 100 & & & 65 & & & 5 \\
\hline Trichoderma & & & & & 70 & 21 & 18 & 55 & 38.5 & 16 \\
\hline Penicillium & & & & & 30 & & 4 & 6.5 & 15 & 21 \\
\hline Fusarium & & & & & & 70 & 13 & 33 & 46.5 & 58 \\
\hline others & & & & & & 9 & & 5.5 & & \\
\hline
\end{tabular}

(d)

\begin{tabular}{|c|c|c|c|c|c|c|c|c|c|c|}
\hline degradation time (days) & 7 & 10 & 14 & 21 & 26 & 33 & 39 & 46 & 59 & 68 \\
\hline Aspergillus & & & & 33.3 & & & 21 & 3 & & \\
\hline Trichoderma & & & & 33.3 & 70 & 75 & 40 & 78 & 74 & 55 \\
\hline Penicillium & & & & 33.3 & 30 & & 21 & 3 & & 24 \\
\hline Fusarium & & & & & & 20 & & 10 & 17 & 21 \\
\hline others & & & & & & 5 & 18 & 6 & 9 & \\
\hline
\end{tabular}

The results were comparable, whether the carbon source was OLA 50 or OLA 96.

Anaerobic bacteria in biosynthesol containing OLA 50 and OLA 96 and in earthworms casts: The presence of anaerobic micro-organisms, in biosynthesol as well as in earthworms casts, had been brought to the fore (figure 4). This shows that the artificial soil used (biosynthesol) contains anaerobic microhabitats, and even earthworms can have anaerobic micro-organisms in their gut.

Evolution of fungi genus in biosynthesol containing OLA 50 and OLA 96 without earthworms and in earthworm casts: Different fungal species were found in earthworm-free biosynthesol and in earthworms casts. The main species were isolated, and their genus were 
determined through microscope observation of mycelium and conidia. There were mainly 4 fungal genera present in biosynthesol (Table 2): Aspergillus, Trichoderma, Penicillium and Fusarium which were also found in earthworms casts. This is not surprising as the genera Aspergillus, Penicillium and Trichoderma are frequently found in soils. Moreover, filamentous fungi such as Fusarium and Penicillium show tolerance towards lactic acid (Torres et al., 1999). At the beginning of the incubation, there was only Aspergillus, which might reflect a contamination of the media. Later on, in worm-free biosynthesol, other species appeared, namely Trichoderma on the $20^{\text {th }}$ day, Penicillium at the $26^{\text {th }}$ day, and Fusarium at the $34^{\text {th }}$ day. The population of these fungi was slightly increased when earthworms were added to the medium. The large deviation found for the distribution of the different genera was assigned to the heterogeneity of the solid medium. As a matter of fact, small areas of different colours could be seen in biosynthesol, proving that there were microhabitats. The sampling was rendered difficult, making data rather inaccurate. Some species disappeared, then appeared again, others seemed to fluctuate.

It is of interest to notice that the population of micro-organisms remained more or less the same from the taxonomic point of view in earthwormfree biosynthesol and in worm casts. These findings agree with those reported by Morgan (1988) who concluded that micro-organisms present in earthworms gut are the same as the ones in the surrounding soil, and that earthworms do not have their own commensal microflora.

The presence of Fusarium was particularly interesting as, according to Torres et al. (1996c), at least one fungus of this genus, $F$. moniliforme, is able to bioassimilate OLA 50 and OLA 100. The number of Fusarium remained stable regardless of the presence of earthworms, their number being apparently greater when OLA 50 was the only carbon source. We have shown in a previous work that earthworms grown in biosynthesol with only OLA 50 or OLA 96 as a sole carbon source could gain weight (Alauzet,1999). Other data (Alauzet, 1999) suggested that earthworms were not responsible for the degradation. It seems that worm-associated micro-organisms pre-degrade OLA, then earthworms eat these micro-organisms and can gain weight. The Fusarium strain found in biosynthesol may be among the main responsible for degradation. However recent results suggested that OLA 50 degrades during the first 27 days of earthworm incubation (Alauzet, 1999), when Fusarium are not yet detected. One may thus suppose that Aspergillus, which appeared very soon and was the only fungus present at the beginning of the incubation, was one of the main filamentous fungi responsible for degradation together with bacteria.

In conclusion, the slight decrease of the number of fungi in the earthworms casts compared to the population found in biosynthesol shows that earthworms regulate the number of fungi mostly by eating them. Among those fungi, Fusarium and Aspergillus strains known as able to bioassimilate PLA (Fusarium, Torres et al., 1996c) or other aliphatic esters (Aspergillus, Nishida et Tokiwa, 1993, Gonsalves et al, 1992) were found. It is thus probable that OLA is first degraded by those fungi and also by bacteria, and then earthworms eat them. Further investigations are needed to determine the exact role of the micro-organisms and to explore whether the identified fungi and bacteria are really able to degrade OLA and to what extent. It is also needed to know whether earthworms can eat those particular fungi, in order to better understand the vermi-microbial interactions in degrading OLA.

\section{ACKNOWLEDGEMENTS}

We thank Pr. Marcel Bouché, from the Soil Zooecology Laboratory, INRA Montpellier, for providing the E.andrei strains.

\section{RESUMO}

Já mostramos que a minhoca Eisenia andrei é capaz de bioassimilar o OLA (oligomeros de ácido lático), uma vez que este último tenha sido prédigerido por microorganismos. A fim de verificar a presênça de microorganismos capazes de degradar os oligomeros de ácido láctico (OLA), as minhocas foram criadas num solo artificial, o biosintesol. $\mathrm{O}$ número de bactérias e fungos nas fezes de minhocas e no biosintesol sem minhoca foi estimado, assim como o gênero dos fungos filamentosos presentes. $O$ resultado mostra uma fraca diminuição do número de microrganismos após sua passagem no instestino das minhocas, sugerindo que as minhocas digerem alguns deles. 
Os principais fungos filamentosos encontrados foram Aspergillus, Trichoderma, Fusarium e Penicillium. Resultados anteriores mostraram que algumas espécies dos gêneros Aspergillus e Fusarium são capazes de degradar o OLA e outros ésteres alifáticos. Sugere-se que esses 2 gêneros e algumas bactérias são responsáveis pela prédegradação do OLA, antes que as minhocas os comam.

\section{REFERENCES}

Alauzet, N. (1999), Etude de la dégradation de polyesters de type poly (acide lactique) en présence de vers de terre. PhD Thesis, Montpellier I University, France.

Abdul Rida, A.; M. and Bouché M. B. (1997), Earthworm toxicology: from acute to chronic tests. Soil Biology and Biochemistry, 29, 699-703

Buchanan, C. M.; Dorsche, D. D.; Gardner, R. M.; Komarek, R. J. and White, A. W. (1995), Biodegradation of cellulose esters: composting of cellulose ester-diluent mixtures. Journal of Macromolecular Science-Pure Applied Chemistry, A32, 683-697

Cortez, J. and Bouché M. B. (1998), Field decomposition of leaf litters : earthworm-microorganisms interactions. The plough-in effect. Soil Biology and Biochemistry, 30, 795-804

Domsch, K. H.; Gams, W. and Anderson, T. H. (1980), Compendium of soil fungi, Academic Press, H. B. Jovanovich Publ., London.

Gonsalves, K. E.; Chen, X. and Cameron, J. A. (1992), Degradation of non-alterning poly (ester-amides). Macromolecules, 25, 3309-3312

Karjomaa, S.; Suortti, T.; Lempiainen, R.; Seli, J. F.; Itavaraa, M. and Steinbuechel, A. (1998), Microbial degradation of poly (lactic acid) oligomers. Biodegradable polymers and macromolecules. Polymer Degradation and Stability, 59, 333-336.

Li, S. M.; Garreau, H. and Vert, M. (1990a), Structureproperty relationships in the case of the degradation of massive poly (alpha-hydroxy acids) in aqueous media. Part 1: Poly (DL-lactic acid). Journal of Materials Science: Materials in Medicine, 1, 123-130
Li, S. M.; Garreau, H. and Vert, M. (1990b), Structureproperty relationships in the case of the degradation of massive poly (alpha-hydroxy acids) in aqueous media. Part 3: Influence of the morphology of poly (L-lactic acid). Journal of Materials Science: Materials in Medicine, 1, 198-206

Morgan, M. H. (1988), The role of micro-organisms in the nutrition of Eisenia fetida. In: Earthworms in waste and environmental management, C. A. Edwards and E. F. Neuhauser (eds), 71-82

Nishida, H. and Tokiwa, Y. (1993), Distribution of poly (b-hydroxybutyrate) and poly (e-caprolactone) aerobic degradaing micro-organisms in different environments. Journal of Environmental Polymer Degradation, 1, 227-233

Parle, J. N. (1963), A microbiological study of earthworm casts. J. General. Microbiol., 31, 13-22

Prescott, L. M.; Harley, J. P. and Klein, D. A. (1996), Microbiology. Wm. C. Brown Publishers, Dubuque, USA, 935p

Torres, A.; Li, S. M.; Roussos, S. and Vert, M. (1996a), Poly (lactic acid) degradation in soil or under controlled conditions. Journal of Applied Polymer Science, 62, 2295-2302.

Torres, A.; Li, S. M.; Roussos, S. and Vert, M. (1996b), Screening of micro-organisms for biodegradation of poly (lactic acid) and lactic acid-containing polymers. Applied and Environmental Biology, 62, 2393-2397

Torres, A.; Li, S. M.; Roussos, S. and Vert, M. (1996c), Degradation of L- and DL-lactic acid oligomers in the presence of Pseudomonas putida and Fusarium moniliforme. Journal of Environmental Polymer Degradation, 4, 213-223

Torres, A.; Li, S. M.; Roussos, S. and Vert, M. (1999), Microbial degradation of a poly (lactic acid) as a model of synthetic polymer degradation mechanisms in outdoor conditions. In: Biopolymers. Utilizing nature's advanced materials, ACS Symposium Series 723, 218-226

Vert, M.; Li, S. M. and Garreau, H. (1981), Bioresorbable polyesters for bone surgery. Makromolekulare Chemie, 5(suppl.), 30-41

Vert, M. and Guerin, P. (1992), Des biosystèmes aux matériaux polymères: une utopie?, Biofutur, Juin, 5257

Vert, M.; Torres, A.; Li, S. M.; Roussos, S. and Garreau, H. (1994), The complexity of the degradation of poly(2-hydroxy-acid)-type aliphatic polyesters. In Biodegradable Plastics and Polymers, Y. Doi and K. Fukuda (Eds). Elsevier, Amsterdam, $11-23$ 